\title{
Studies and Mechanism of Olefination Reaction in Aryl-Enolates with Paraformaldehyde
}

\author{
Jonathan Román Valdéz-Camacho¹, José Domingo Rivera-Ramírez², Jaime Escalante ${ }^{{ }^{*}}$ \\ ${ }^{1}$ Centro de Investigación en Ciencias-IICBA, Universidad Autónoma del Estado de Morelos, \\ Cuernavaca, México \\ ${ }^{2}$ Centro Universitario de Ciencias Exactas e Ingenierías, Departamento de Química, Universidad de Guadalajara, \\ Guadalaja, México \\ Email: ‘jaime@uaem.mx
}

How to cite this paper: Valdéz-Camacho, J.R., Rivera-Ramírez, J.D. and Escalante, J. (2019) Studies and Mechanism of Olefination Reaction in Aryl-Enolates with Paraformaldehyde. International Journal of Organic Chemistry, 9, 10-22.

https://doi.org/10.4236/ijoc.2019.91002

Received: December 19, 2018

Accepted: January 14, 2019

Published: January 17, 2019

Copyright $\odot 2019$ by author(s) and Scientific Research Publishing Inc. This work is licensed under the Creative Commons Attribution International License (CC BY 4.0).

http://creativecommons.org/licenses/by/4.0/

\begin{abstract}
A simple, efficient and low-cost methodology for the synthesis of $\alpha$-aryl- $\alpha, \beta$ unsaturated esters using paraformaldehyde as a source of carbon was developed. Factors that control reaction yields such as temperature, concentration and reaction time were evaluated. A mechanism is proposed based on experimental structures of the intermediates.
\end{abstract}

\section{Keywords \\ Olefination, Paraformaldehyde, $\alpha$-Aryl- $\alpha, \beta$-Unsaturated Ester, a-Methylenation}

\section{Introduction}

The $\alpha$-substituted acrylic acid analogs or derivatives are a dynamic key synthon in the construction of interesting molecules due to their capacity to act as Michael acceptors [1] [2] [3] [4] [5], Diels-Alder dienes [6] or Aza-Morita-BaylisHillman reaction substrates [7]. These molecules include drugs, bioactive compounds, process impurities and advanced synthetic intermediates [8] [9]. As a result, several methods to synthesize these synthons have been reported (Figure 1) [10] [11].

One of the most common choices of aldehyde for $\alpha$-substituted- $\alpha, \beta$-unsaturated compound through aldol condensation is formaldehyde where the reaction is typically known as $\alpha$-methylenation [12] [13] [14].

Excellent works about the use of aqueous formaldehyde as methylenation agent via Mannich reaction have been published. For example, in 2006, Erkkilä and Pihko have performed the formation of $\alpha$-methylenated aldehydes, also 


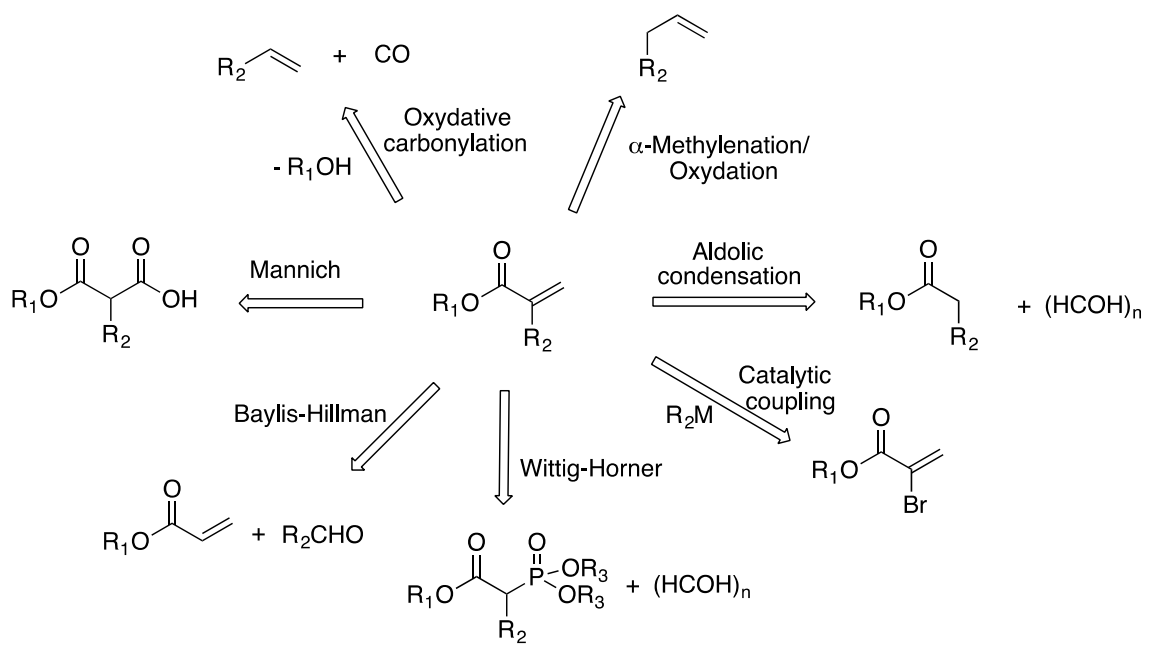

Figure 1. Strategies for the synthesis of acrylates.

called $\alpha$-substituted acroleines, using aqueous formaldehyde and secondary amines as a catalyst [12]. Several studies employing other aldehydes and different types of alkyl, cyclic, aryl ketones and esters have been developed using diisopropylammonium trifluoroacetate salt [13] or Meldrum's acid as a catalyst.

On the other hand, and in addition to Mannich reaction, one of the most useful strategies for the formation of $\alpha, \beta$-unsaturated systems is the aldol condensation [15] [16] due to its efficiency and low cost. In this transformation, the $\alpha$-carbon of an enolate is bonded with the carbonyl carbon of an aldehyde, and a $\beta$-hydroxylated-carbonyl intermediate is obtained. Most of the times, a $\beta$-dehydration is observed as part of the process, and an $\alpha, \beta$-unsaturated compound is isolated. On the other hand, when a functionalized aldehyde is employed, a trans- $\beta$-substituted- $\alpha, \beta$-unsaturated compound is obtained [17] [18]. Rodriguez et al. [19] reported that when both enolate and aldehyde are functionalized, the corresponding product is an $\alpha, \beta$-disubstituted- $\alpha, \beta$-unsaturated compound. They also mentioned that with this method, stereochemistry control of this reaction proved to be nontrivial.

Even though the aldol reaction employing formaldehyde is useful in the formation of $\alpha$-methylenated carbonyl compounds, there are few reports about its use. One of the early reports was that of Laos in 1967 [20] where the $\alpha$-methylenation of steroidal ketones was carried out with aqueous formaldehyde and potassium acetate as base and methanol or water as solvents. Recently, Liu studied the effect of the acidity of zeolite in the formation of acrylic acid and methyl acrylate from formaldehyde and methyl acetate [21].

A useful and practical source of formaldehyde is paraformaldehyde, a polymer, due to it is a versatile and easily handled reactively. For example, Amri et al. [22] used paraformaldehyde as homologate agent by substituting phosphonate group in the Honer-Wadsworth-Emmons reaction type synthesis of ( \pm )-homosarkomycin with $98 \%$ of yield. An aldol type $\alpha$-methylenation of lactones employing paraformaldehyde, which gives moderate to good yields was performed 
by Tanaka and Yamashita [23]. Chen et al. [24] also prepared $\alpha$-nitro ethyl acrylate intermediates using paraformaldehyde, which was then employed as $\mathrm{Mi}$ chael acceptor in the synthesis of tryptophan derivatives.

Traditionally, it is accepted that aqueous formaldehyde and paraformaldehyde are two different sources of the same monomeric reactive and that the only advantage that paraformaldehyde has is that it can be used in water free reactions or solvents.

In the present work, we propose a possible mechanistic pathway of aldol condensation using paraformaldehyde, which is different from that observed in formaldehyde.

\section{Results and Discussion}

\subsection{Reaction of Methyl Phenylacetate (1a) with Sodium Hydride and Paraformaldehyde (3)}

Currently, our research group is interested in the synthesis of $\boldsymbol{\beta}^{2}$-and $\boldsymbol{\beta}^{3}$-amino acids via aza-Michael addition to $\boldsymbol{\alpha}, \boldsymbol{\beta}$-unsaturated esters [25]. One of our method of choice is a facile synthesis of 2-aryl methyl acrylates (4a-d); retrosynthetic approximation is shown in Scheme 1.

In the present study, initially, methyl phenylacetate (1a), paraformaldehyde (3) and $\mathrm{NaH}$ were chosen as starting materials. Acrylate 4 a synthesis was carried out using toluene as solvent and microwave (MW) heating. Table 1 and Scheme 2 summarize experimental results for different solvents, reaction times, and sources of activation energy.

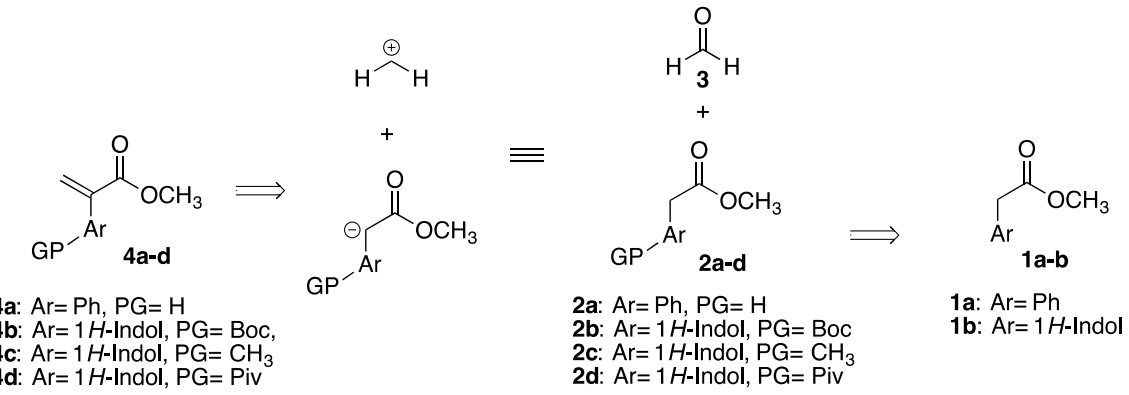

Scheme 1. Retrosynthetic analysis for the preparation of 2-aryl methyl acrylates.

Table 1. Reaction conditions and yields for the aldol condensation of $1 \mathrm{a}$ and 3.

\begin{tabular}{|c|c|c|c|c|c|c|c|c|c|c|}
\hline \multirow{2}{*}{ Entry } & \multirow{2}{*}{$\begin{array}{c}1 \mathrm{a} \\
(\mathrm{mmol})\end{array}$} & \multirow{2}{*}{$\begin{array}{c}3 \\
(\mathrm{eq})\end{array}$} & \multirow{2}{*}{$\begin{array}{c}\mathrm{NaH} \\
(\mathrm{eq})\end{array}$} & \multirow{2}{*}{ Solvent } & \multirow{2}{*}{$\begin{array}{c}\text { Source } \\
\text { energy } \\
\text { activation }\end{array}$} & \multirow{2}{*}{$\begin{array}{l}\text { Time } \\
\text { (h) }\end{array}$} & \multicolumn{4}{|c|}{ Yield (\%) } \\
\hline & & & & & & & $4 a$ & 5 & $6 a$ & 7 \\
\hline 1 & 3.3 & 3 & 1.5 & Toluene & MW & 1 & $-^{a}$ & 55 & - & - \\
\hline 2 & 3.3 & 9 & 3 & Toluene & MW & 3 & 60 & - & - & - \\
\hline 3 & 16.6 & 9 & 3 & Toluene & MW & 1.5 & 87 & - & - & - \\
\hline 4 & 66.6 & 9 & 3 & Toluene & r. t. & 1.6 & 11 & - & 29 & 5 \\
\hline 5 & 33.3 & 9 & 3 & Toluene & $55^{\circ} \mathrm{C}^{\mathrm{b}}$ & 1 & 87 & - & - & - \\
\hline 6 & 33.3 & 9 & 3 & THF & $55^{\circ} \mathrm{C}^{\mathrm{b}}$ & 0.25 & 62 & - & - & - \\
\hline
\end{tabular}

a. Traces of product $4 \mathrm{a}, \mathrm{b}$. Temperature of addition of the reagents. 


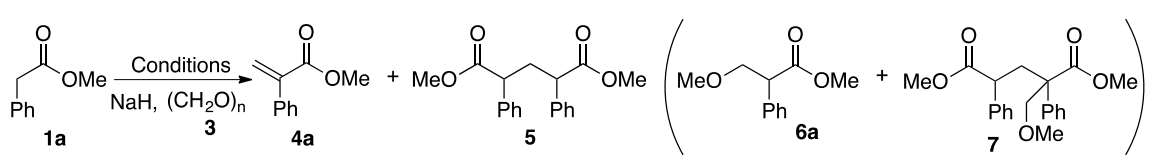

Scheme 2. Aldol condensation reaction of 1a and 3.

The first entry in Table 1 shows the result of the formation of the acrylate $4 \mathrm{a}$ using 1.5 equiv. of $\mathrm{NaH}$ in toluene and $\mathrm{MW}$ heating for $1 \mathrm{~h}$. Compound 5 was isolated as the main product with $55 \%$ yield and only traces of 4 a (entry 1). An increase of paraformaldehyde from 3 to 9 equiv. and of $\mathrm{NaH}$ from 1.5 to 3 equiv., results in a better yield (60\%) of acrylate $4 \mathrm{a}$ (entry 2$)$. On the other hand, when the reaction is carried out with $16.6 \mathrm{mmol}$ of $1 \mathrm{a}$, acrylate $4 \mathrm{a}$ was isolated in higher yield (87\% yield, entry 3 ). When the reaction is carried out at room temperature, $4 \mathrm{a}$ was obtained with a smaller yield and $\mathbf{6 a}$, and $\mathbf{7}$ were also produced in $29 \%$ and $5 \%$ yields, respectively (entry 4). For this last experiment, it is relevant mentioning that after $1 \mathrm{~h}$, the reaction spontaneously generated an exothermic from $25^{\circ} \mathrm{C}$ to $55^{\circ} \mathrm{C}$.

When the reaction was carried out at $55^{\circ} \mathrm{C}$, after $1 \mathrm{~h}$ only $4 \mathrm{a}$ was obtained with $87 \%$ yield (entry 5). The result suggests that temperature can be used to control the production of byproducts $\mathbf{6} \mathbf{a}$ and $\mathbf{7 a}$. Finally, in order to explore the solvent effect, the reaction was carried out in THF at the same temperature with a better yield of $4 \mathrm{a}$ in only 15 min (entry 6 ).

Scheme 3 proposes a reaction mechanism for the formation of $4 a, 5,6 a$, and 7. The enolate of $1 \mathrm{a}$ carried out a nucleophilic substitution over paraformaldehyde, and the intermediate 10 was produced.

From there on, the reaction could generate $4 \mathrm{a}$ through a $\beta$-elimination $\left(\mathrm{E}_{\beta}\right.$, Path 1) and subsequently a Michael addition of the enolate of $1 \mathrm{a}$ on $4 \mathrm{a}$ to form the corresponding compound 5 .

Alternatively, two products could be generated via Path 2. 6a is obtained through a nucleophilic substitution by the hydride; and 7 was isolated through the Michael addition of $\mathbf{4 a}$ and the enolate $\mathbf{6} \mathbf{a}$.

Recrystallization of 7, afforded a suitable crystal for X-ray diffraction analysis. The resulting structure is presented in Figure 2.

\subsection{Synthesis of Acrylates Derivatives 4b, 4c, and 4d}

We chose to examine the synthesis of other acrylates: $\mathbf{4 b}, \mathbf{4 c}$, and $\mathbf{4 d}$ under the conditions of entry 6 in Table 1 which are optimized from the reaction time and solvent choice point of view. For this purpose, we first synthesized $2 \mathbf{b}, \mathbf{2 c}$, and 2d (see Scheme 4).

Due to the structural diversity presented in methyl esters $2 \mathrm{~b}, 2 \mathrm{c}$, and $2 \mathrm{~d}$, a general synthetic route to these compounds was not available. Below, we describe two methodologies, including some developed by our research group.

Compound $\mathbf{1 b}$ was first esterified with methanol in the presence of TMSCl. $\mathbf{2} \mathbf{b}$ and $2 \mathrm{~d}$ were then synthesized through of the addition of $(\mathrm{Boc})_{2} \mathrm{O}$ or pivaloyl 


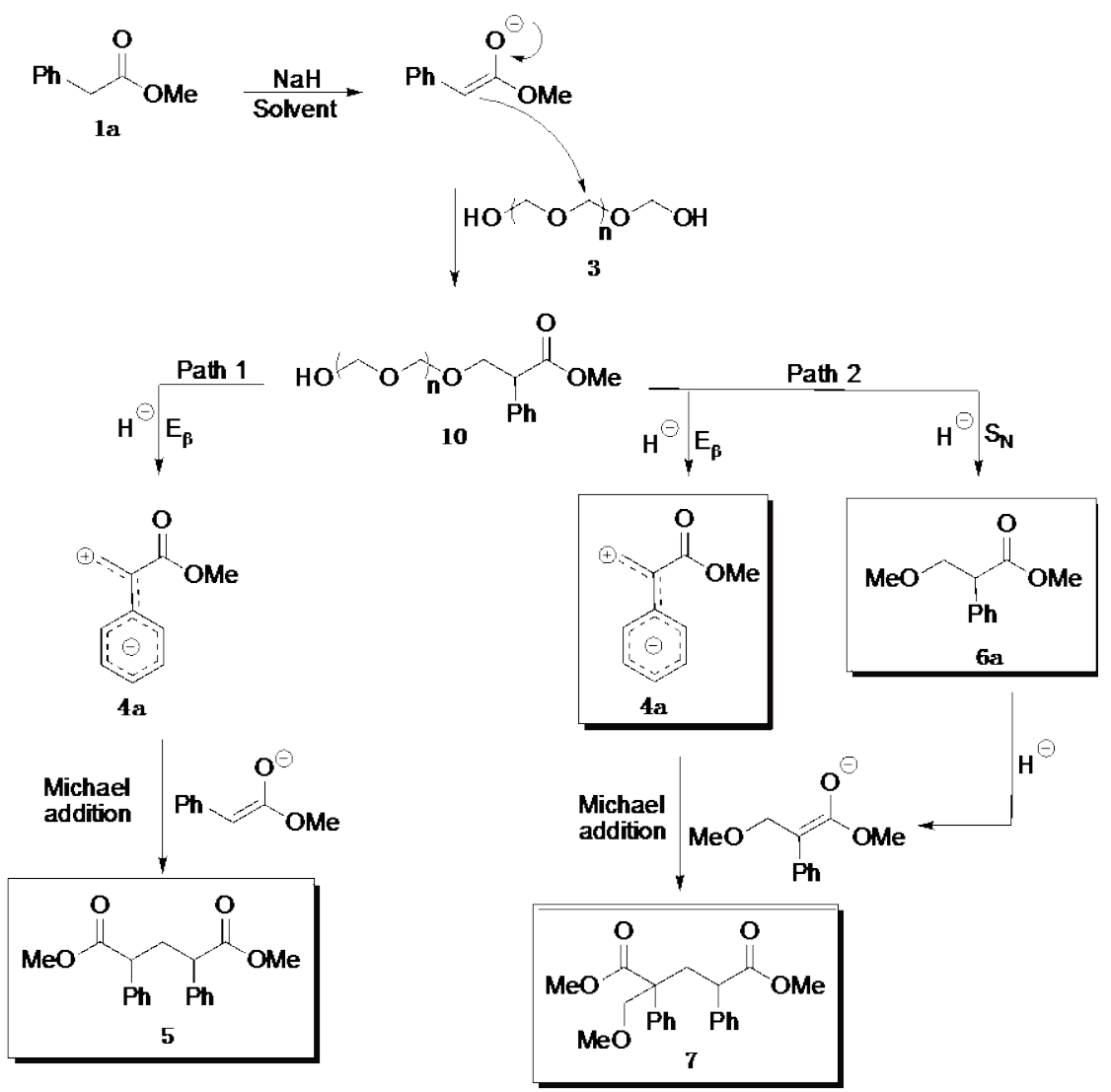

Scheme 3. Mechanism approach for the isolation of byproducts 5, $6 \mathrm{a}$ and 7 .

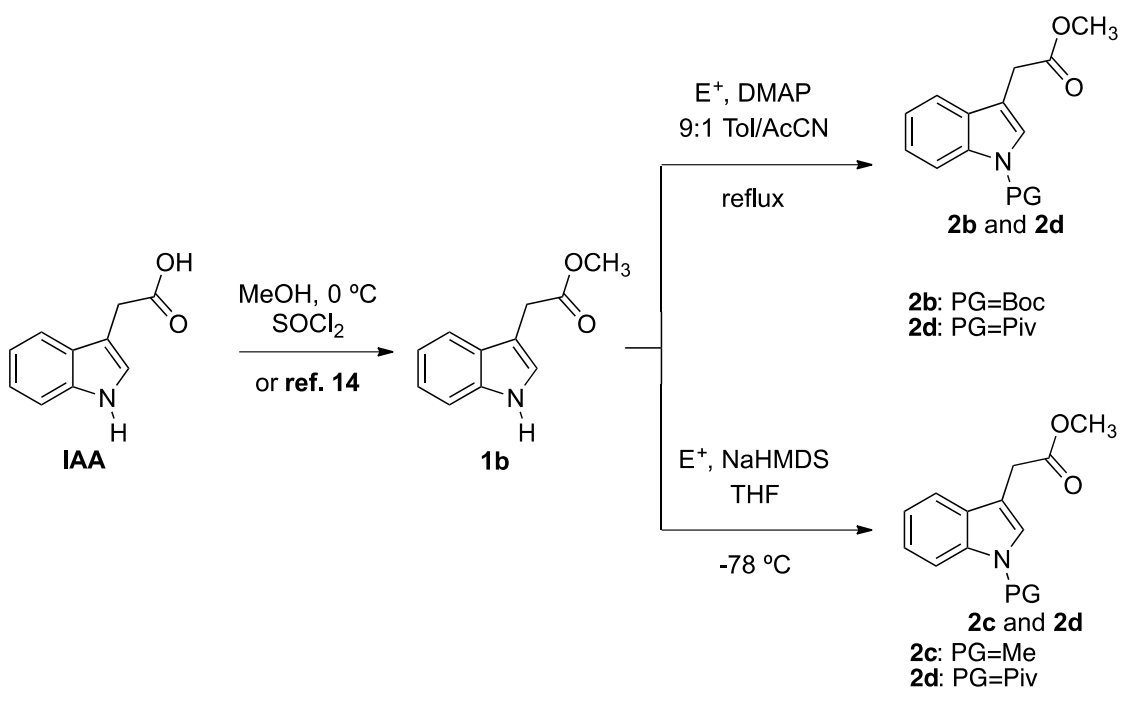

Scheme 4. Syntheses of derivatives $2 \mathrm{~b}-\mathrm{d}$.

chloride, with 4-DMPA as a catalyst in a mixture of Toluene/AcCN 9:1 as solvent at reflux. On the other hand, $2 \mathrm{~d}$ can also be produced by the addition of NaHMDS to $1 \mathrm{~b}$ in THF at $-78^{\circ} \mathrm{C}$.

Recrystallization of $\mathbf{2 d}$ afforded suitable crystal for X-ray diffraction analysis shown in Figure 3. 


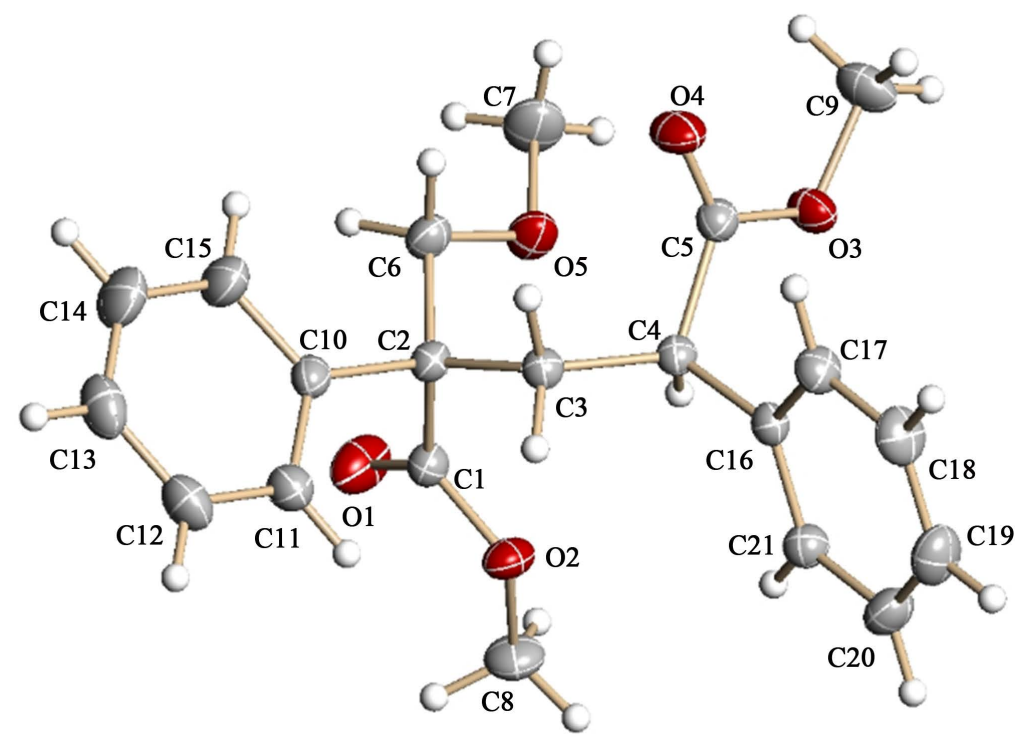

Figure 2. X-ray structure of 7.

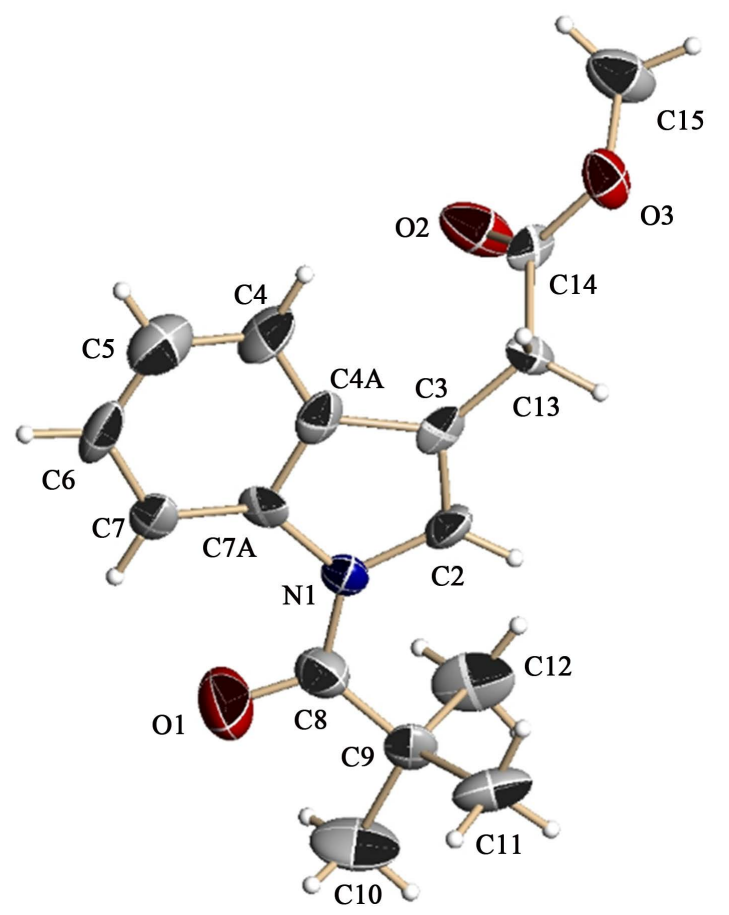

Figure 3. X-ray structure of $2 \mathrm{~d}$.

Having produced $2 \mathrm{~b}, \mathbf{2 c}$, and $\mathbf{2 d}$, we then proceed with the syntheses of the acrylates $4 \mathrm{~b}, \mathbf{4 c}$, and $\mathbf{4 d}$. The results of this series are summarized in Table 2.

As expected from the results shown in Table 1, the desired acrylates derivatives $4 \mathrm{~b}$ and $4 \mathrm{c}$ were obtained in $50 \%$ and $62 \%$ yield respectively. After purification of $4 \mathrm{~b}$ by column chromatography, traces of $6 \mathrm{~b}$ were found (entries 1 and 2 , Table 2 and Scheme 5). It is worth mentioning that the product $4 \mathrm{~d}$ could not be obtained under these reaction conditions, but surprisingly one side product (8d) was isolated in $37 \%$ yield. 


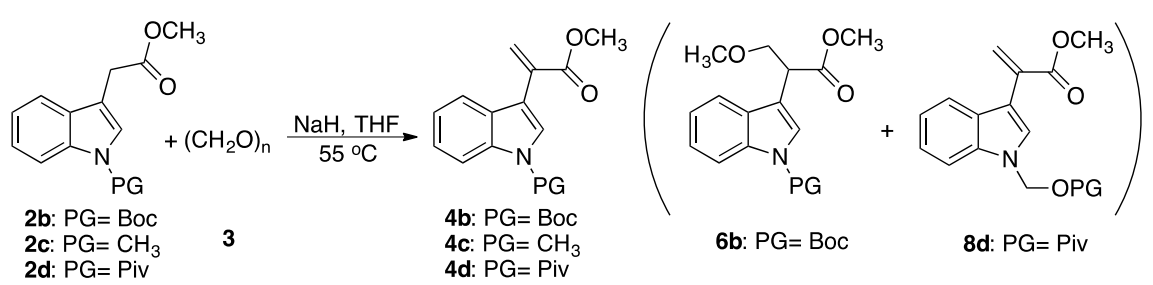

Scheme 5. Aldol condensation reaction of $2 \mathrm{a}-\mathrm{c}$ and 3.

Table 2. Reaction conditions and yields for the aldol condensation of $\mathbf{2 b} \mathbf{b}-\mathbf{d}$ with $\mathbf{3}$.

\begin{tabular}{ccccccccc}
\hline Entry & 2 & PG & $3(\mathrm{eq})$ & $\mathrm{NaH}(\mathrm{eq})$ & Time $(\mathrm{h})$ & $4(\%)$ & $6(\%)$ & $8(\%)$ \\
\hline 1 & b & Boc & 9 & 3 & 0.25 & 50 & $-^{\mathrm{a}}$ & - \\
2 & c & Me & 9 & 3 & 0.25 & 62 & - & - \\
3 & d & Piv & 9 & 3 & 0.25 & - & - & 37 \\
\hline
\end{tabular}

${ }^{a}$ Traces of product $6 \mathrm{~b}$.

Similar to the case of $\mathbf{2 b}$, here we expect to obtain either $\mathbf{4 d}$ or $\mathbf{6 d}$. Instead, we found $\mathbf{8 d}$ a product of rearrangement reaction. We hypothesize that this compound formed by the insertion of a $-\mathrm{CH}_{2} \mathrm{O}$-moiety from paraformaldehyde between the protector group and the indole (Scheme 6).

\section{Conclusion}

In summary, although the classical mechanism for this olefination reaction suggests that the paraformaldehyde is dissociated to formaldehyde when it is warmed, and then it reacts with the enolate to get the aldol product and its subsequent dehydration. However, in this study, we demonstrate that the addition of a carbon atom from paraformaldehyde to give rise to the vinyl group occurs through a series of nucleophilic substitutions catalyzed by hydride over acetalic carbons from the polymer.

\section{Experimental}

\section{Experimental Materials and Methods}

The course of the reactions was followed by TLC. Silica gel of $70-230$ mesh of Merk (Darmstad, Germany) was used for purification of the products by flash chromatography. Methyl phenyl-acetate (1a), 3-indoleacetic acid and paraformaldehyde (3) were purchased from Aldrich and used without further purification.

\section{Analytical Methods}

Spectra data of ${ }^{1} \mathrm{H}$ NMR and ${ }^{13} \mathrm{C}$ NMR were obtained in $\mathrm{CDCl}_{3}$ solutions with TMS as internal standard on Varian Gemini 200, Varian Oxford 400, and Inova 400 spectrometers. Mass spectral analyses were carried out in a spectrometer JEOL model JMS-AX50SHA.

Methyl 2-(1 H-Indol-3-yl) Acetate $1 b$.

In a flask of $250 \mathrm{~mL}$ provided with magnetic stirrer, $5.0 \mathrm{~g}(28.54 \mathrm{mmol})$ of 3-indolacetic acid and $50 \mathrm{~mL}$ of $\mathrm{MeOH}$ were added. The flask was cooled at $0^{\circ} \mathrm{C}$ 


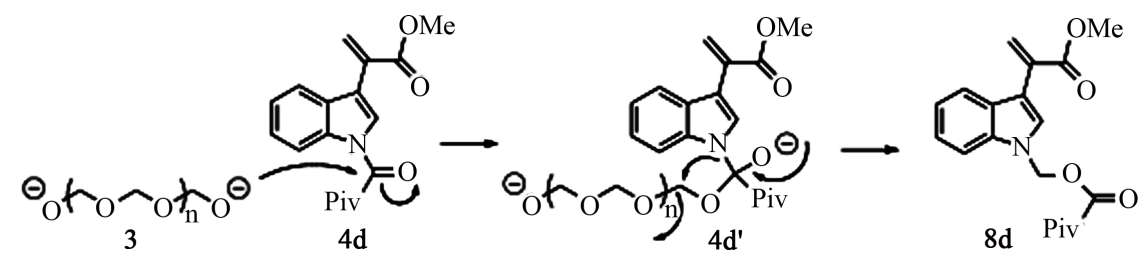

Scheme 6. A proposed mechanism for the formation of $\mathbf{8 d}$.

and then $2.5 \mathrm{~mL}$ ( $4.08 \mathrm{~g}, 34.27 \mathrm{mmol}, 1.2$ equiv.) of thionyl chloride. The mixture was stirred during $1 \mathrm{~h}$, and then a saturated $\mathrm{K}_{2} \mathrm{CO}_{3}$ solution was added until getting $8-9 \mathrm{pH}$. Methanol was evaporated, and the solution was extracted with ethyl acetate $(3 \times 30 \mathrm{~mL})$. The organic phase was dried over $\mathrm{Na}_{2} \mathrm{SO}_{4}$ anhydrous. Concentration in a rotatory evaporator gave the crude product, which was purified by flash chromatography (n-hexane/ethyl acetate, 70:30 - 50:50). Red oil, yield 97\%. ${ }^{1} \mathrm{H}$ NMR $\left(\mathrm{CDCl}_{3}, 400 \mathrm{MHz}\right), \delta(\mathrm{ppm}): 3.72\left(\mathrm{~s}, 3 \mathrm{H}, \mathrm{OCH}_{3}\right) ; 3.80\left(\mathrm{~d},{ }^{3} J\right.$ $\left.=0.8 \mathrm{~Hz}, 2 \mathrm{H}, \mathrm{CH}_{2} \mathrm{CO}\right) ; 7.04\left(\mathrm{~d},{ }^{3} \mathrm{~J}=2.4 \mathrm{~Hz}, \mathrm{H}, \mathrm{NHCH}\right) ; 7.18\left(\mathrm{~m}, 2 \mathrm{H}, \mathrm{C}^{5} \mathrm{H}-\mathrm{C}^{6} \mathrm{H}\right)$; $7.29\left(\mathrm{~d},{ }^{3} J=8.4 \mathrm{~Hz}, \mathrm{H}, \mathrm{C}^{4} \mathrm{H}\right) ; 7.63\left(\mathrm{~d},{ }^{3} J=7.6 \mathrm{~Hz}, \mathrm{H}, \mathrm{C}^{7} \mathrm{H}\right) ; 8.16$ (br, s, H, NH). ${ }^{13} \mathrm{C} \mathrm{NMR}\left(\mathrm{CDCl}_{3}, 100 \mathrm{MHz}\right), \delta(\mathrm{ppm}): 31.1\left(\mathrm{OCH}_{3}\right) ; 31.9\left(\mathrm{CH}_{2} \mathrm{CO}\right) ; 108.2(\mathrm{C}-3)$; 111.2 (C-4); 118.7 (C-7); 119.6 (C-5); 122.1 (C-6); 123.2 (C-2); $127.2\left(\mathrm{C}_{\text {ipso }}-3 \mathrm{a}\right)$; $136.2\left(\mathrm{C}_{\text {ipso }}-7 \mathbf{a}\right) ; 172.7\left(\mathrm{CH}_{2} \mathrm{CO}\right)$. HRMS (FAB+): calcd. for $\mathrm{C}_{11} \mathrm{H}_{11} \mathrm{NO}_{2}\left[\mathrm{M}^{+}\right]$: 189.2140, found: $\mathrm{C}_{11} \mathrm{H}_{12} \mathrm{NO}_{2}\left[\mathrm{M}+\mathrm{H}^{+}\right]: 190.0880$.

General procedure 1:

In a flask provided with magnetic stirrer $1 \mathbf{b}$ (or c), 1.1 equiv. of $(\mathrm{Boc})_{2} \mathrm{O}, 0.1$ equiv. of 4-DMAP and a 9:1 Toluene: $\mathrm{CH}_{3} \mathrm{CN}$ mixture were added. The reaction mixture was refluxed for $3 \mathrm{~h}$. The mixture of solvents was evaporated, and then $\mathrm{H}_{2} \mathrm{O}$ was added and extracted with ethyl acetate. The organic phase was dried over $\mathrm{Na}_{2} \mathrm{SO}_{4}$ anhydrous. Concentration in a rotatory evaporator gave the crude product, which was purified by flash chromatography (n-hexane/ethyl acetate).

General procedure 2:

In a flask provided with a magnetic stirrer and $\mathrm{N}_{2}$ atmosphere, $1 \mathrm{c}$ (or $\mathrm{d}$ ) and $50 \mathrm{~mL}$ of THF anhydrous were added. The flask was cooled at $-78^{\circ} \mathrm{C}$ and then 1.1 equiv. of NaHMDS and 1.2 equiv. of protective reagent. The mixture was stirred during $2 \mathrm{~h}$, and then a saturated $\mathrm{K}_{2} \mathrm{CO}_{3}$ solution was added until getting 8 - $9 \mathrm{pH}$. The solution was extracted with ethyl acetate. The organic phase was dried over $\mathrm{Na}_{2} \mathrm{SO}_{4}$ anhydrous. Concentration in a rotatory evaporator gave the crude product, which was purified by flash chromatography (n-hexane/ethyl acetate).

General procedure 3:

In a flask of $100 \mathrm{~mL}$ provided with magnetic stirrer 5 equiv. of $\mathrm{NaH} 60 \%$ were added to $50 \mathrm{~mL}$ of $\mathrm{n}$-hexane. The mixture was stirred during $15 \mathrm{~min}$, the $\mathrm{n}$-hexane was subtracted, and $50 \mathrm{~mL}$ of THF were then added. The flask was cooled at $0^{\circ} \mathrm{C}$ and then 2, 9 equiv. of paraformaldehyde were added. The reaction mixture was stirred for $1 \mathrm{~h}, 20 \mathrm{~mL}$ of water were added, and the solution was extracted with diethyl ether $(3 \times 10 \mathrm{~mL})$. Concentration in a rotatory evaporator gave the crude product, which was purified by flash chromatography 
(n-hexane/ethyl acetate).

tert-Butyl 3-(2-Methoxy-2-Oxoethy)-1H-Indole-1-Carboxylate $2 \boldsymbol{b}$.

According to General Procedure 2, in a flask of $250 \mathrm{~mL}, 5.0 \mathrm{~g}(26.43 \mathrm{mmol})$ of 1b, $6.34 \mathrm{~g}(29.068 \mathrm{mmol})$ of $(\mathrm{Boc})_{2} \mathrm{O}, 0.32 \mathrm{~g}(2.64 \mathrm{mmol})$ of 4-DMAP and 100 $\mathrm{mL}$ of a 9:1 Toluene:AcCN mixture were added. Green solid, yield 97\%. m.p.: 58 ${ }^{\circ} \mathrm{C} .{ }^{1} \mathrm{H} \mathrm{NMR}\left(\mathrm{CDCl}_{3}, 200 \mathrm{MHz}\right), \delta(\mathrm{ppm}): 1.96\left(\mathrm{~s}, 9 \mathrm{H}, \mathrm{OC}\left(\mathrm{CH}_{3}\right)_{3}\right) ; 4.01(\mathrm{~s}, 5 \mathrm{H}$, $\left.\mathrm{CH}_{2} \mathrm{COOCH}_{3}\right) ; 7.58\left(\mathrm{~m}, 2 \mathrm{H}, \mathrm{C}^{5} \mathrm{H}-\mathrm{C}^{6} \mathrm{H}\right) ; 7.82\left(\mathrm{~d},{ }^{3} \mathrm{~J}=8.0 \mathrm{~Hz}, \mathrm{H}, \mathrm{C}^{4} \mathrm{H}\right) ; 7.87(\mathrm{~s}, \mathrm{H}$, $\mathrm{NCH}) ; 8.45\left(\mathrm{~d},{ }^{3} \mathrm{~J}=8.0 \mathrm{~Hz}, \mathrm{H}, \mathrm{C}^{7} \mathrm{H}\right) .{ }^{13} \mathrm{C} \mathrm{NMR}\left(\mathrm{CDCl}_{3}, 50 \mathrm{MHz}\right), \delta(\mathrm{ppm}): 28.4$ $\left(\mathrm{OC}\left(\mathrm{CH}_{3}\right)_{3}\right) ; 31.1\left(\mathrm{OCH}_{3}\right) ; 52.3\left(\mathrm{CH}_{2} \mathrm{CO}\right) ; 83.8\left(\mathrm{OC}\left(\mathrm{CH}_{3}\right)_{3}\right) ; 113.2(\mathrm{C}-3) ; 115.4$ (C-7); 119.1 (C-4); 122.7 (C-6); 124.5 (C-5); 124.6 (C-2); $130.1\left(\mathrm{C}_{\text {ipso }}\right.$-3a); 135.5 $\left(\mathrm{C}_{\text {ipso }}-7 \mathrm{a}\right) ; 149.6(\mathrm{OCON}) ; 171.5\left(\mathrm{CH}_{2} \mathrm{CO}\right)$. Anal. Calcd. for $\mathrm{C}_{16} \mathrm{H}_{19} \mathrm{NO}_{4}: \mathrm{C} 66.42$, H 6.62; N, 4.84; found: C 66.10, H 6.49, N 4.66.

Methyl2-(1-Methyl-1H-Indol-3-yl) Acetate 2c.

According to General Procedure 2, $0.48 \mathrm{~g}(2.54 \mathrm{mmol})$ of $1 \mathrm{~b}, 2.8 \mathrm{~mL}(2.8$ $\mathrm{mmol})$ of NaHMDS and $0.19 \mathrm{~mL}(3.04 \mathrm{mmol})$ of iodomethane were added. Colorless oil, yield 29\%. ${ }^{1} \mathrm{H} \mathrm{NMR}\left(\mathrm{CDCl}_{3}, 200 \mathrm{MHz}\right), \delta$ (ppm): 3.68 (s, 3H, $\mathrm{NCH}_{3}$ ); 3.73 (s, $\left.3 \mathrm{H}, \mathrm{OCH}_{3}\right) ; 3.76\left(\mathrm{~s}, 2 \mathrm{H}, \mathrm{CH}_{2} \mathrm{CO}\right) ; 7.02(\mathrm{~s}, \mathrm{H}, \mathrm{NCH}) ; 7.14(\mathrm{~m}, 2 \mathrm{H}$, $\left.\mathrm{C}^{5} \mathrm{H}-\mathrm{C}^{6} \mathrm{H}\right) ; 7.28\left(\mathrm{~d},{ }^{3} \mathrm{~J}=7.0 \mathrm{~Hz}, \mathrm{H}, \mathrm{C}^{4} \mathrm{H}\right) ; 7.58\left(\mathrm{~d},{ }^{3} \mathrm{~J}=10.0 \mathrm{~Hz}, \mathrm{H}, \mathrm{C}^{7} \mathrm{H}\right) .{ }^{13} \mathrm{C}$ NMR $\left(\mathrm{CDCl}_{3}, 50 \mathrm{MHz}\right), \delta(\mathrm{ppm}): 31.2\left(\mathrm{NCH}_{3}\right) ; 32.8\left(\mathrm{OCH}_{3}\right) ; 52.0\left(\mathrm{CH}_{2} \mathrm{CO}\right)$; 105.1 (C-3); 106.9 (C-4); 109.4 (C-7); 119.0 (C-5); 119.3 (C-6); 121.9 (C-2); $127.8\left(\mathrm{C}_{\text {ipso }}-7 \mathrm{a}\right) ; 137.0\left(\mathrm{C}_{\text {ipso }}-3 \mathrm{a}\right) ; 172.7\left(\mathrm{CH}_{2} \mathrm{CO}\right)$. HRMS (FAB+): calcd. for $\mathrm{C}_{12} \mathrm{H}_{13} \mathrm{NO}_{2}\left[\mathrm{M}^{+}\right]:$203.2410, found: $\mathrm{C}_{12} \mathrm{H}_{13} \mathrm{NO}_{2}\left[\mathrm{M}^{+}\right]: 203.0946$.

Methyl 2-(1-Pivaloyl-1 H-Indol-3-yl) Acetate 2d.

According to General Procedure 2, $0.5 \mathrm{~g}$ (2.64 mmol) of methyl 1b, $2.9 \mathrm{~mL}$ $(2.9 \mathrm{mmol})$ of NaHMDS and $0.39 \mathrm{~mL}(3.17 \mathrm{mmol})$ of trimethylacetyl chloride were added. Colorless solid, yield $29 \%$. m.p.: $108^{\circ} \mathrm{C}-111^{\circ} \mathrm{C} .{ }^{1} \mathrm{H}$ NMR $\left(\mathrm{CDCl}_{3}\right.$, $200 \mathrm{MHz}), \delta(\mathrm{ppm}): 1.52\left(\mathrm{~s}, 9 \mathrm{H},\left(\mathrm{CH}_{3}\right)_{3} \mathrm{CO}\right) ; 3.74\left(\mathrm{~s}, 3 \mathrm{H}, \mathrm{OCH}_{3}\right) ; 3.75\left(\mathrm{~d},{ }^{3} J=2.0\right.$ $\left.\mathrm{Hz}, 2 \mathrm{H}, \mathrm{CH}_{2} \mathrm{CO}\right) ; 7.32\left(\mathrm{~m}, 2 \mathrm{H}, \mathrm{C}^{5} \mathrm{H}-\mathrm{C}^{6} \mathrm{H}\right) ; 7.52$ (d, $\left.{ }^{3} J=8.0 \mathrm{~Hz}, \mathrm{H}, \mathrm{C}^{4} \mathrm{H}\right) ; 7.80$ (s, $\mathrm{H}, \mathrm{NCH}) ; 8.51\left(\mathrm{~d},{ }^{3} J=8.0 \mathrm{~Hz}, \mathrm{H}, \mathrm{C}^{7} \mathrm{H}\right) .{ }^{13} \mathrm{C} \mathrm{NMR}\left(\mathrm{CDCl}_{3}, 50 \mathrm{MHz}\right), \delta(\mathrm{ppm})$ : $28.6\left(\mathrm{OC}\left(\mathrm{CH}_{3}\right)_{3}\right) ; 30.7\left(\mathrm{OCH}_{3}\right) ; 41.2\left(\mathrm{OC}\left(\mathrm{CH}_{3}\right)_{3}\right) ; 52.1\left(\mathrm{CH}_{2} \mathrm{CO}\right) ; 104.9$ (C-3); 113.8 (C-7); 117.4 (C-4); 118.4 (C-6); 123.5 (C-5); 124.2 (C-2); $129.0\left(\mathrm{C}_{\text {ipso }}\right.$-3a); $136.9\left(\mathrm{C}_{\text {ipso }}-7 \mathrm{a}\right) ; 171.3\left(\left(\mathrm{CH}_{3}\right)_{3} \mathrm{CO}\right) ; 176.8\left(\mathrm{CH}_{2} \mathrm{CO}\right)$. HRMS (FAB+): calcd. for $\mathrm{C}_{16} \mathrm{H}_{19} \mathrm{NO}_{3}\left[\mathrm{M}^{+}\right]: 273.3320$, found: $\mathrm{C}_{16} \mathrm{H}_{20} \mathrm{NO}_{3}\left[\mathrm{M}+\mathrm{H}^{+}\right]:$274.1457. X-Ray crystallographic structure in Figure 2 [26].

\section{Methyl 2-Phenyl-Acrylate 4 a.}

In a flask of $250 \mathrm{~mL}$ provided with a magnetic stirrer and $\mathrm{N}_{2}$ atmosphere $4.0 \mathrm{~g}$ (100 mmol, 3 equiv.) of $\mathrm{NaH} 60 \%$ were added to $50 \mathrm{~mL}$ of $\mathrm{n}$-hexane. The mixture was stirred during $15 \mathrm{~min}$, the $\mathrm{n}$-hexane was subtracted, and $125 \mathrm{~mL}$ of THF was then added. The flask was cooled at $0^{\circ} \mathrm{C}$, and then $5 \mathrm{~g}(33.31 \mathrm{mmol}, 1$ equiv.) of $2 \mathrm{a}, 9 \mathrm{~g}$ (299.9 mmol, 9 equiv.) of paraformaldehyde was added. The reaction mixture was heated to $50^{\circ} \mathrm{C}-53^{\circ} \mathrm{C}$ for around $8 \mathrm{~min}$, intense reflux was initiated, and the mixture immediately turns yellow. Then $50 \mathrm{~mL}$ of water was added, and the solution was extracted with ethyl acetate $(3 \times 20 \mathrm{~mL})$. Concentration in a rotatory evaporator gave the crude product, which was purified by flash 
chromatography (n-hexane/ethyl acetate, 80:20 - 60:40). Colorless oil, yield 87\%. ${ }^{1} \mathrm{H} \mathrm{NMR}\left(\mathrm{CDCl}_{3}, 400 \mathrm{MHz}\right) \delta(\mathrm{ppm}): 3.81\left(\mathrm{~s}, 3 \mathrm{H}, \mathrm{CH}_{3} \mathrm{O}\right) ; 5.88(\mathrm{~d}, J=1.2 \mathrm{~Hz}$, $\left.1 \mathrm{H}, \mathrm{CH}_{\text {b-gem }}\right), 6.36\left(\mathrm{~d}, J=1.2,1 \mathrm{H}, \mathrm{CH}_{\text {a-gem }}\right), 7.10-7.41(\mathrm{~m}, 5 \mathrm{H}, \mathrm{Ph}) .{ }^{13} \mathrm{C} \mathrm{NMR}$ $\left(\mathrm{CDCl}_{3}, 100 \mathrm{MHz}\right) \delta 52.3\left(\mathrm{CH}_{3} \mathrm{O}\right), 126.9\left(\mathrm{CH}_{2}=\mathrm{C}\right), 128.2(\mathrm{CPh}), 128.3(\mathrm{CPh})$, $128.4(\mathrm{CPh}), 136.8\left(\mathrm{C}_{\text {ipso }} \mathrm{Ph}\right), 141.4\left(\mathrm{C}=\mathrm{CH}_{2}\right), 167.3\left(\mathrm{COOCH}_{3}\right)$. HRMS (EI): calcd. for $\mathrm{C}_{10} \mathrm{H}_{10} \mathrm{O}_{2}[\mathrm{M}]^{+}: 162.0681$, found: $\mathrm{C}_{10} \mathrm{H}_{10} \mathrm{O}_{2}: 162.0070$.

tert-Butyl 3-(3-Methoxy-3-Oxoprop-1-en-2-yI)-1 H-Indole-1-Carboxylate 4 b.

According to General Procedure 3, $0.52 \mathrm{~g}(1.8 \mathrm{mmol})$ of $2 \mathrm{~b}, 0.36 \mathrm{~g}(9 \mathrm{mmol})$ of $\mathrm{NaH} 60 \%$ and $0.486 \mathrm{~g}(16.18 \mathrm{mmol})$ of paraformaldehyde were added. Green oil, yield 50\%. ${ }^{1} \mathrm{H} \mathrm{NMR}\left(\mathrm{CDCl}_{3}, 400 \mathrm{MHz}\right), \delta(\mathrm{ppm}): 1.28\left(\mathrm{~s}, 9 \mathrm{H}, \mathrm{OC}\left(\mathrm{CH}_{3}\right)_{3}\right)$; $3.35\left(\mathrm{~s}, 3 \mathrm{H}, \mathrm{OCH}_{3}\right) ; 5.85\left(\mathrm{~d},{ }^{2} J_{\text {gem }}=8.0 \mathrm{~Hz}, \mathrm{H}, \mathrm{CCH}_{2}\right) ; 6.37\left(\mathrm{~d},{ }^{2} J_{\text {gem }}=8.0 \mathrm{~Hz}, \mathrm{H}\right.$, $\left.\mathrm{CCH}_{2}\right) ; 7.11\left(\mathrm{t},{ }^{3} \mathrm{~J}=8.0 \mathrm{~Hz}, \mathrm{H}, \mathrm{C}^{6} \mathrm{H}\right) ; 7.22\left(\mathrm{t},{ }^{3} \mathrm{~J}=8.0 \mathrm{~Hz}, \mathrm{H}, \mathrm{C}^{5} \mathrm{H}\right) ; 7.545\left(\mathrm{~d},{ }^{3} J=\right.$ $\left.8.0 \mathrm{~Hz}, \mathrm{H}, \mathrm{C}^{4} \mathrm{H}\right) ; 8.08$ (s, H, NCH); 8.46 (br, s, H, C $\left.{ }^{7} \mathrm{H}\right) .{ }^{13} \mathrm{C} \mathrm{NMR}\left(\mathrm{CDCl}_{3}, 100\right.$ $\mathrm{MHz}): 28.4\left(\mathrm{OC}\left(\mathrm{CH}_{3}\right)_{3}\right) ; 31.0\left(\mathrm{OCH}_{3}\right) ; 52.5\left(\mathrm{CH}_{2} \mathrm{CO}\right) ; 84.1\left(\mathrm{OC}\left(\mathrm{CH}_{3}\right)_{3}\right) ; 115.6$ $149.4(\mathrm{CPh}) ; 167.0\left(\mathrm{CH}_{2} \mathrm{CO}\right)$. HRMS (ESI): calcd. for $\mathrm{C}_{17} \mathrm{H}_{19} \mathrm{NO}_{4}[\mathrm{M}]^{+}$: 301.3420, found: $\mathrm{C}_{17} \mathrm{H}_{20} \mathrm{NO}_{4}\left[\mathrm{M}+\mathrm{H}^{+}\right]$: 302.1398 .

Methyl 2-(1-Methyl-1 H-Indol-3-yl) Acrylate 4 c.

According to General Procedure 3, $0.52 \mathrm{~g}(2.56 \mathrm{mmol})$ of $2 \mathrm{c}, 0.512 \mathrm{~g}$ (12.79 $\mathrm{mmol})$ of $\mathrm{NaH} 60 \%$ and $0.692 \mathrm{~g}(23.04 \mathrm{mmol})$ of paraformaldehyde were added. Green oil, yield $62 \% .{ }^{1} \mathrm{H}$ NMR $\left(\mathrm{CDCl}_{3}, 400 \mathrm{MHz}\right), \delta$ (ppm): 3.78 (s, $3 \mathrm{H}, \mathrm{NCH}_{3}$ ); $3.85\left(\mathrm{~s}, 3 \mathrm{H}, \mathrm{OCH}_{3}\right) ; 6.11\left(\mathrm{~d},{ }^{2} J_{\text {gem }}=1.2 \mathrm{~Hz}, \mathrm{H}, \mathrm{CCH}_{2}\right) ; 6.34\left(\mathrm{~d},{ }^{2} J_{\text {gem }}=1.2 \mathrm{~Hz}, \mathrm{H}\right.$, $\mathrm{CCH}_{2}$ ); 7.44 (m, 3H, C $\left.{ }^{4} \mathrm{H}-\mathrm{C}^{5} \mathrm{H}-\mathrm{C}^{6} \mathrm{H}\right) ; 7.49(\mathrm{~s}, 1 \mathrm{H}, \mathrm{NCH}) ; 7.76\left(\mathrm{~d},{ }^{3} \mathrm{~J}=7.0 \mathrm{~Hz}, \mathrm{H}\right.$, $\left.\mathrm{C}^{6} \mathrm{H}-\mathrm{C}^{7} \mathrm{H}\right) .\left(\mathrm{CDCl}_{3}, 100 \mathrm{MHz}\right), \delta(\mathrm{ppm}): 33.1\left(\mathrm{OCH}_{3}\right) ; 52.3\left(\mathrm{CH}_{2} \mathrm{CO}\right) ; 109.7$

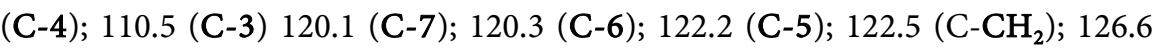
$\left(\mathrm{C}-\mathrm{CH}_{2}\right) ; 130.1(\mathrm{C}-2) ; 133.9\left(\mathrm{C}_{i p s o}-3 \mathrm{a}\right) ; 137.2\left(\mathrm{C}_{i p s o}-7 \mathrm{a}\right) ; 167.9\left(\mathrm{CH}_{2} \mathrm{CO}\right)$. Dimethyl 2,4-Diphenylpentanedioate 5.

Isolated as a byproduct from $2 \mathrm{a}$ reaction conditions such as is shown in Table 1, Entry 1. Colorless oil, yield 55\%. Erythro and Threo mixture. ${ }^{1} \mathrm{H}$ NMR $\left(\mathrm{CDCl}_{3}, 400 \mathrm{MHz}\right) \delta(\mathrm{ppm}): 2.57\left(\mathrm{~m}, 2 \mathrm{H}, \mathrm{CH}_{2} \mathrm{CH}\right), 3.41\left(\mathrm{~m}, 1 \mathrm{H}, \mathrm{CHCH}_{2}\right), 3.60$ $\left(\mathrm{s}, \mathrm{s}, 6 \mathrm{H}, \mathrm{CH}_{3} \mathrm{O}\right), 7.27(\mathrm{~m}, 10 \mathrm{H}, \mathrm{Ph}) .{ }^{13} \mathrm{C} \mathrm{NMR}\left(\mathrm{CDCl}_{3}, 100 \mathrm{MHz}\right) \delta(\mathrm{ppm}): 36.7$ $\left(\mathrm{CH}_{2} \mathrm{CH}\right), 49.1\left(\mathrm{CHCH}_{2}\right), 52.3\left(\mathrm{CH}_{3} \mathrm{O}\right), 127.8(\mathrm{CPh}), 128.0(\mathrm{CPh}), 128.9(\mathrm{CPh})$, $138.2\left(\mathrm{C}_{\text {ipso }}-\mathrm{Ph}\right), 173.8\left(\mathrm{COOCH}_{3}\right)$. HRMS: calcd. for $\mathrm{C}_{19} \mathrm{H}_{20} \mathrm{O}_{4}[\mathrm{M}]^{+}:$312.1362, found: $\mathrm{C}_{19} \mathrm{H}_{20} \mathrm{O}_{4}: 312.3470$.

Methyl3-Methoxy-2-Phenylpropanoate 6a.

Isolated as byproduct from $2 \mathrm{a}$ reaction conditions such as is shown in Table 1, Entry 7. Colourless oil, yield 29\%. ${ }^{1} \mathrm{H}$ NMR $\left(\mathrm{CDCl}_{3}, 400 \mathrm{MHz}\right) \delta$ (ppm): 3.36 (s, $3 \mathrm{H}, \mathrm{CH}_{3} \mathrm{OCH}_{2}$ ), 3.57 (dd, $J=8.4 \mathrm{~Hz}, J=4.4 \mathrm{~Hz}, 1 \mathrm{H}, \mathrm{CHPh}$ ), $3.69(\mathrm{~s}, 3 \mathrm{H}$, $\mathrm{CH}_{3} \mathrm{OCO}$ ), $3.91\left(\mathrm{dd}, J=9.6 \mathrm{~Hz}, J=4.4 \mathrm{~Hz}, 1 \mathrm{H}, \mathrm{CH}_{2} \mathrm{CH}\right.$ ), $3.99(\mathrm{dd}, J=9.4 \mathrm{~Hz}, J$ $\left.=8.4 \mathrm{~Hz}, 1 \mathrm{H}, \mathrm{CH}_{2} \mathrm{CH}\right), 7.35(\mathrm{~m}, 5 \mathrm{H}, \mathrm{Ph}) .{ }^{13} \mathrm{C} \mathrm{NMR}\left(\mathrm{CDCl}_{3}, 100 \mathrm{MHz}\right) \delta 52.0$ $\left(\mathrm{CH}_{3} \mathrm{OCH}_{2}\right), 52.3(\mathrm{CHPh}), 59.2\left(\mathrm{CH}_{3} \mathrm{OCO}\right), 74.4\left(\mathrm{CH}_{2} \mathrm{CH}\right), 127.8(\mathrm{CPh}), 128.1$ $(\mathrm{CPh}), 128.8(\mathrm{CPh}), 135.7\left(\mathrm{C}_{i p s o}-\mathrm{Ph}\right), 172.9\left(\mathrm{COOCH}_{3}\right)$. HRMS: calcd. for $\mathrm{C}_{11} \mathrm{H}_{14} \mathrm{O}_{3}[\mathrm{M}]^{+}:$: 194.0943, found: $\mathrm{C}_{11} \mathrm{H}_{14} \mathrm{O}_{3}: 194.0990$.

Dimethyl 2-(Methoxymethyl)-2,4-Diphenylpentanedioate 7.

Isolated as byproduct from $2 \mathrm{a}$ reaction conditions such as is shown in Table 
1, Entry 6. Colourless oil, yield 11\%. Diastereomers and enantiomers mixture. ${ }^{1} \mathrm{H}$ NMR $\left(\mathrm{CDCl}_{3}, 400 \mathrm{MHz}\right) \delta(\mathrm{ppm}): 2.80\left(\mathrm{~m}, 2 \mathrm{H}, \mathrm{CH}_{2} \mathrm{CH}\right), 3.20(\mathrm{~s}, 3 \mathrm{H}$, $\mathrm{CH}_{3} \mathrm{OC}$ ), 3.35 (m, 1H, CHPh), 3.45 (s, 3H, $\mathrm{CH}_{3} \mathrm{OCO}$ ), 3.83 (s, 3H, $\mathrm{CH}_{3} \mathrm{OCO}$ ), $3.90\left(\mathrm{~m}, 2 \mathrm{H}, \mathrm{CH}_{2} \mathrm{C}\right), 7.25(\mathrm{~m}, 10 \mathrm{H}, 2 \mathrm{Ph}) .{ }^{13} \mathrm{C} \mathrm{NMR}\left(\mathrm{CDCl}_{3}, 100 \mathrm{MHz}\right) \delta(\mathrm{ppm})$ : $36.9\left(\mathrm{CH}_{2} \mathrm{CH}\right), 50.0(\mathrm{CHPh}), 52.8\left(\mathrm{CH}_{3} \mathrm{OCOCH}\right), 53.2\left(\mathrm{CH}_{3} \mathrm{OCOC}\right), 75.7$ $\left(\mathrm{CH}_{2} \mathrm{C}\right), 128.1\left(\mathrm{C}_{i p s o}-\mathrm{Ph}\right), 136.6(\mathrm{CPh}), 141.0\left(\mathrm{C}_{i p s o}-\mathrm{Ph}\right), 174.3\left(\mathrm{CHC}(\mathrm{O}) \mathrm{OCH}_{3}\right)$, $177.4\left(\mathrm{CC}(\mathrm{O}) \mathrm{OCH}_{3}\right)$. HRMS: calcd. for $\mathrm{C}_{21} \mathrm{H}_{24} \mathrm{O}_{5}[\mathrm{M}]^{+}$: 356.1624, found: $\mathrm{C}_{21} \mathrm{H}_{24} \mathrm{O}_{5}$ $[\mathrm{M}+\mathrm{Na}]^{+}:$379.1517. X-Ray crystallographic structure in Figure 1 [27].

Methyl 2-(1-((Pivaloyloxy) methyl)-1 H-Indol-3-yl) Acrylate $8 d$.

According to General Procedure 3, $0.52 \mathrm{~g}$ ( $1.9 \mathrm{mmol})$ of $2 \mathrm{~d}, 0.38 \mathrm{~g}(9.5 \mathrm{mmol})$ of $\mathrm{NaH} 60 \%$ and $0.514 \mathrm{~g}(17.12 \mathrm{mmol})$ of paraformaldehyde were added. Green-yellow oil, yield 37\%. ${ }^{1} \mathrm{H}$ NMR $\left(\mathrm{CDCl}_{3}, 400 \mathrm{MHz}\right), \delta(\mathrm{ppm}): 1.14(\mathrm{~s}, 9 \mathrm{H}$, $\left.\left(\mathrm{CH}_{3}\right)_{3} \mathrm{CO}\right) ; 3.84\left(\mathrm{~s}, 3 \mathrm{H}, \mathrm{OCH}_{3}\right) ; 6.07\left(\mathrm{~s}, 2 \mathrm{H}, \mathrm{NCH}_{2} \mathrm{O}\right) ; 6.13\left(\mathrm{~d},{ }^{2} J_{g e m}=1.2 \mathrm{~Hz}, \mathrm{H}\right.$, $\left.\mathrm{CCH}_{2}\right) ; 6.41\left(\mathrm{~d},{ }^{2} J_{g e m}=1.2 \mathrm{~Hz}, \mathrm{H}, \mathrm{CCH}_{2}\right) ; 7.21\left(\mathrm{td},{ }^{3} J_{1}=1.2 \mathrm{~Hz},{ }^{3} J_{2}=7.2 \mathrm{~Hz}, \mathrm{H}\right.$, $\left.\mathrm{C}^{6} \mathrm{H}\right) ; 7.28\left(\mathrm{td},{ }^{3} J_{1}=1.2 \mathrm{~Hz},{ }^{3} J_{2}=7.2 \mathrm{~Hz}, \mathrm{H}, \mathrm{C}^{5} \mathrm{H}\right) ; 7.49\left(\mathrm{~d},{ }^{3} \mathrm{~J}=8.4 \mathrm{~Hz}, \mathrm{H}, \mathrm{C}^{4} \mathrm{H}\right)$; 7.64 (s, H, NCH); $7.72\left(\mathrm{~d},{ }^{3} J=8.0 \mathrm{~Hz}, \mathrm{H}, \mathrm{C}^{7} \mathrm{H}\right) .{ }^{13} \mathrm{C} \mathrm{NMR}\left(\mathrm{CDCl}_{3} 100 \mathrm{MHz}\right), \delta$ (ppm): $26.9\left(\mathrm{OC}\left(\mathrm{CH}_{3}\right)_{3}\right) ; 38.9\left(\mathrm{OC}\left(\mathrm{CH}_{3}\right)_{3}\right) ; 52.1\left(\mathrm{OCH}_{3}\right) ; 68.7\left(\mathrm{NCH}_{2} \mathrm{O}\right) ; 109.9$

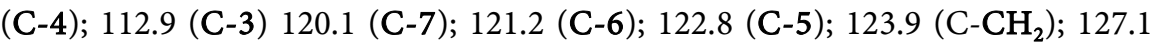
$\left(\mathrm{C}-\mathrm{CH}_{2}\right) ; 129.3(\mathrm{C}-2) ; 133.4\left(\mathrm{C}_{i p s o}-3 \mathrm{a}\right) ; 136.4\left(\mathrm{C}_{i p s o}-7 \mathrm{a}\right) ; 167.4\left(\left(\mathrm{CH}_{3}\right)_{3} \mathrm{CO}\right) ; 178.0$ $\left(\mathrm{CH}_{2} \mathrm{CCO}\right)$. HRMS (FAB+): calcd. for $\mathrm{C}_{18} \mathrm{H}_{21} \mathrm{NO}_{4}[\mathrm{M}]^{+}:$315.3690, found: $\mathrm{C}_{17} \mathrm{H}_{20} \mathrm{NO}_{4}\left[\mathrm{M}+\mathrm{H}^{+}\right]: 316.1537$.

\section{Acknowledgements}

We are grateful to CONACYT for financial support (Project No. CB2015/256653). J.R. V.-C. gratefully acknowledges CONACYT for a scholarship.

\section{Conflicts of Interest}

The authors declare no conflicts of interest regarding the publication of this paper.

\section{References}

[1] Yamago, S., Iida, K. and Yoshida, J.-I. (2002) Tailored Synthesis of Structurally Defined Polymers by Organotellurium-Mediated Living Radical Polymerization (TERP): Synthesis of Poly(meth)acrylate Derivatives and Their Di- and Triblock Copolymers. Journal of the American Chemical Society, 124, 13666-13667. https://doi.org/10.1021/ja027599i

[2] Pignatello, R., Bucolo, C., Spedalieri, G., Maltese, A. and Puglisi, G. (2002) Flurbiprofen-Loaded Acrylate Polymer Nanosuspensions for Ophthalmic Application. Biomaterials, 23, 3247-3255. https://doi.org/10.1016/S0142-9612(02)00080-7

[3] Nguyen, L.H., Straub, M. and Gu, M. (2005) Acrylate-Based Photopolymer for Two-Photon Microfabrication and Photonic Applications. Advanced Functional Materials, 15, 209-216. https://doi.org/10.1002/adfm.200400212

[4] Metz, N. and Theato, P. (2007) Controlled Synthesis of poly(acetone oxime acrylate) as a New Reactive Polymer: Stimuli-Responsive Reactive. European Polymer Journal, 43, 1202-1209. https://doi.org/10.1016/j.eurpolymj.2007.01.009 
[5] Kiyota, H., Takai, T., Saitoh, M., Nakayama, O., Takayuki, O. and Kuwahara, S. (2004) Facile Synthesis of (-)-tabtoxinine- $\beta$-lactam and Its (3'R)-Isomer. Tetrahedron Letters, 45, 8191-8194. https://doi.org/10.1016/j.tetlet.2004.09.033

[6] Erkkilä, A., Majander, I. and Pihko, P. (2007) Iminium Catalysis. Chemical Reviews, 107, 5416-5470. https://doi.org/10.1021/cr068388p

[7] Shi, Y. and Shi, M. (2007) Aza-Baylis-Hillman Reactions and Their Synthetic Applications. European Journal of Organic Chemistry, 2905-2916. https://doi.org/10.1002/ejoc.200700030

[8] Fernandes, L., Bortoluzzi, A.J. and Sá, M.M. (2004) Simple Access to 2-Methylalk2-Enoates and Insect Pheromones by Zinc-Promoted Reduction of Baylis-HillmanDerived Allylic Bromides. Tetrahedron, 60, 9983-9989.

https://doi.org/10.1016/j.tet.2004.08.018

[9] An, L.-T., Zou, J.-P. and Zhang, L.-L. (2008) Polymer-Supported Sulphonic Acid Catalyzed Cross-Aldol Condensation: An Expeditious Synthesis of $\alpha$, $\alpha$-bis(substituted Benzylidene) Cycloalkanones. Catalysis Communications, 9, 349-354. https://doi.org/10.1016/j.catcom.2007.06.004

[10] Sarkar, B.R. and Chaudhari, R.V. (2005) Carbonylation of Alkynes, Alkenes, and Alcohols Using Metal Complex Catalysts. Catalysis Surveys from Asia, 9, 193-205. https://doi.org/10.1007/s10563-005-7556-x

[11] Hon, Y.-S., Liu, Y.-W. and Hsieh, C.-H. (2004) Dibromomethane as One-Carbon Source in Organic Synthesis: A Versatile Methodology to Prepare the Cyclic and Acyclic Methylene or $\alpha$-Keto Acid Derivatives from the Corresponding Terminal Alkenes. Tetrahedron, 60, 4837-4860. https://doi.org/10.1016/j.tet.2004.04.013

[12] Erkkilä, A. and Pihko, P.M. (2006) Mild Organocatalytic-Methylenation of Aldehydes. Journal of Organic Chemistry, 71, 2538-2541. https://doi.org/10.1021/jo052529q

[13] Bugarin, A., Jones, K.D. and Connell, B.T. (2010) Efficient, Direct $\alpha$-Methylenation of Carbonyls Mediated by Diisopropylammonium Trifluoroacetate. Chemical Communications, 10, 1715-1717. https://doi.org/10.1039/b924577d

[14] Giguère, D., Cloutier, P. and Roy, R. (2009) Domino Heck/Lactonization-Catalyzed Synthesis of 3-C-Linked Mannopyranosyl Coumarins. Journal of Organic Chemistry, 74, 8480-8483. https://doi.org/10.1021/jo901855p

[15] Mandal, S., Mandal, S., Ghosh, S.K., Ghosh, A., Saha, R., Banerjee, S. and Saha, B. (2016) Review of the Aldol Reaction. Synthetic Communications, 46, 1327-1342. https://doi.org/10.1080/00397911.2016.1206938

[16] Machajewski, T.D. and Wong, C.-H. (2000) The Catalytic Asymmetric Aldol Reaction. Angewandte Chemie International Edition, 39, 1352-1374.

https://doi.org/10.1002/(SICI)1521-3773(20000417)39:8<1352::AID-ANIE1352>3.0. CO;2-J

[17] Wang, J., Lei, M., Li, Q., Ge, Z., Wang, X. and Li, R. (2009) A Novel and Efficient Direct Aldol Condensation from Ketones and Aldehydes Catalyzed by Proline-TEA through a New Pathway. Tetrahedron, 65, 4826-4833. https://doi.org/10.1016/j.tet.2009.04.052

[18] Hora, L., Kelbichová, V., Kikhtyanin, O., Bortnovskiy, O. and Kubicka, D. (2014) Aldol Condensation of Furfural and Acetone over Mg-Al Layered Doublé Hydroxides and Mixed Oxides. Catalysis Today, 223, 138-147. https://doi.org/10.1016/j.cattod.2013.09.022

[19] Habib-Zahmani, H., Hacini, S., Bories, C., Faure, R. and Rodriguez, J. (2005) An Operationally Simple Base-Catalyzed Multi-Component Domino Transformation: 
Stereoselective Preparation on Trisubstituted Alkenes and 1,3-Dienes. Synthesis, 36, 2151-2156.

[20] Laos, I. (1967) Direct Methylenation of Steroidal $\alpha, \beta$-Epoxy Ketones. Journal of Organic Chemistry, 32, 1409-1413. https://doi.org/10.1021/jo01280a026

[21] Ma, Z., Ma, X., Ni, Y., Liu, H., Zhu, W., Guo, X. and Liu, Z. (2018) HZSM-35 Zeolite Catalyzed Aldol Condensation Reaction to Prepare Acrylic Acid and Its Ester: Effect of Its Acidic Property. Chinese Journal of Catalysis, 39, 1762-1769. https://doi.org/10.1016/S1872-2067(18)63145-6

[22] Samarat, A., Fargeas, V., Villiéras, J., Lebreton, J. and Amri, H. (2001) A New Synthesis of $( \pm)$-Homosarkomycin Ethyl Ester. Tetrahedron Letters, 42, 1273-1274. https://doi.org/10.1016/S0040-4039(00)02238-3

[23] Tanaka, A. and Yamashita, K. (1978) A Simple Procedure for $\alpha$-Methylenation or $\gamma$ and $\delta$-Lactones. Agricultural and Biological Chemistry, 42, 1585-1588. https://doi.org/10.1080/00021369.1978.10863208

[24] Sui, Y., Liu, L., Zhao, J.-L., Wang, D. and Chen, Y.-J. (2007) An Efficient One-Pot Reaction of Indoles, Nitroacetates, and Paraformaldehyde for the Synthesis of Tryptophan Derivatives. Tetrahedron Letters, 48, 3779-3782. https://doi.org/10.1016/j.tetlet.2007.04.002

[25] Rangel, H., Carrillo-Morales, M., Galindo, J.M., Castillo, E., Obregón-Zúñiga, A., Juaristi, E. and Escalante, J. (2015) Structural Features of $N$-Benzylated- $\beta$-Amino Acid Methyl Esters Essential for Enantio Differentiation by LIPASE B from Candida Antarctica in Hydrolytic Reactions. Tetrahedron: Asymmetry, 26, 325-332. https://doi.org/10.1016/j.tetasy.2015.02.007

[26] Crystallographic Data Is Deposited at Cambridge Crystallographic Data Center CCDC: No. 1877662.

[27] Crystallographic Data Is Deposited at Cambridge Crystallographic Data Center CCDC: No. 1876262. 